\title{
Effects of Exogenous Multi-enzyme Feed Additive (Kemzyme) on the Activities of Certain Digestive Enzymes and Intestinal Morphology in Growing Rabbits
}

\author{
Attia. K.A. \\ Department of Physiology, Faculty of Veterinary Medicine, Cairo University \\ Egypt Faculty of Veterinary Medicine, Cairo University, Giza-12211, Egypt \\ Tel: 20-201-0003-9399 E-mail: Kamalattia173@hotmail.com \\ Sohair Y. Saleh (Corresponding author) \\ Department of Physiology, Faculty of Veterinary Medicine, Cairo University \\ Egypt Faculty of Veterinary Medicine, Cairo University, Giza-12211, Egypt \\ Tel: 20-233-386-6209 E-mail: Sohair_saleh@hotmail.com
}

S.Abd El-hamidSafaa

Department of Biochemistry, Animal Health Research Institute, Dokki, Egypt

Tel: 20-111-215-405 E-mail: Safaa1962@hotmail.com

A.ZakiAmal

Department of Biochemistry, Animal Health Research Institute, Dokki, Egypt

Tel: 20-105-759-949_E-mail: am_zaki35 @yahoo.com

A.El-Sawy Mohamed

Department of Rabbit, Animal Production Research Institute, Dokki, Egypt

Tel: 20-122-3023-801Ｅ-mail: Elsawyprod@yahoo.com

Received: July 11, 2011

Accepted: July 25, $2011 \quad$ Online Published: December 29, 2011

doi:10.5539/jas.v4n3p35

URL: http://dx.doi.org/10.5539/jas.v4n3p35

\begin{abstract}
The study aimed to investigate the effects of exogenous digestive enzymes supplement on the activity of endogenous digestive enzymes and the histomorphology of the intestinal mucosa in growing rabbits. Two groups of growing rabbits $(\mathrm{n}=10 / \mathrm{each})$ were used, control and supplemented groups. Animals of supplemented group were given $1 \%$ Kemzyme mixed in the ration for 8 successive weeks. Results revealed (1) significant increase in the final body weight and blood levels of glucose, total lipids and total protein, (2) significant increase in the activities of amylase, lipase and protease of serum, pancreatic tissues and intestinal contents, and (3) significant improvement in the villus length and crypt depth of the intestinal mucosa. Conclusively, it was obvious that the higher growth rate in kemzyme-supplemented rabbits was associated with improved digestive enzymatic activities and intestinal morphology. Also, it seemed that the exogenous enzymes did not get affected by the endogenous proteolytic activity of the gastro intestinal tract.
\end{abstract}

Keywords: Multi-enzyme feed additive, Digestive enzyme, Intestinal histomorphology, Rabbit

\section{Introduction}

Rabbit is single stomach herbivore. Its digestive system is suitable for high cellulose diet. Many experiments have indicated that high cellulose diet is favorable for depressing death rate by the mechanism, appendix vigor, which stimulates ileum. Considering the health of intestinal tract, crude protein concentration in diet for the growing rabbits should be lower than that for fattening rabbits (16 and 16.5 respectively), Xiangmei (2008). Simple 
biological characteristics, short breeding cycle, high prolificacy and better feed conversion efficiency logically place ranks rabbit just below poultry (Hasanat et al., 2006). The poor and green grass Ad-libitum unbalanced quality of forage based diets, usually provided to rabbits in developing countries was described by (Cheeke et al., 1985). Despite these obvious advantages, improved feed formulation and strategies for enhancing the production and reproduction potentials of rabbit especially in tropical and subtropical regions of the world have not been fully exploited.

The benefits of adding enzymes to diets of non ruminant animals particularly poultry, has become more common in recent years (Campell and Bedford, 1992). Current developments in this area include digestibility of starch and non-starch polysaccharides in cereals. The exogenous enzyme supplementations are well documented (Bedford and Classen 1992). These enzymes can partially hydrolyze non soluble protein (NSP), reduce the viscosity of gut contents, and result in improvements in nutrient absorption. Several studies have also demonstrated that the intestinal morphology was affected beneficially in birds fed barley-based diets (Brenes et al., 1993) or decrease the small intestinal fermentation attributed to high NSP diets (Choct et al., 1996).

Several studies have been attempted for incorporating exogenous enzymes into rabbit diets to improve nutrients availability, however in most trials, rabbits appeared lessble responsive and variable effects were observed on their performances (Remóis et al., 1996; Fernandez et al., 1996; Pinheiro and Almeida, 2000; Falcão-e-Cunha et al., 2004; Garcia et al., 2005; Falcao-e-Cunha et al., 2007). The decrease in mortality (García et al., 2005) found with proteases and proteases + xylanases (probably reducing protein flow to the caecum) was the most prominent finding. Some positive results were also obtained by other researchers.

Eiben et al., (2004), testing cellulase, got improvements in FCR and mortality of rabbits weaned at 23 days of age, whereas ADG was unaffected. It is interesting to note that in some trials enzymes improved fibre digestibility. Fernandez et al., (1996) and Bolis et al., (1996). The latter authors got significant improvements when cellulase and enzyme pool (xylanase, b-glucanase, b-gluccosidase, pentosanase, myloglucosidase, acid and neutral protease) was added on NDF $(+5 \%)$ and ADF $(+13 \%)$ digestibilities, yet at the same time getting reductions of digestible and metabolizable energies, and nitrogen balance, in comparison with the control diets.

However, relatively few studies have been conducted on intestinal morphology and endogenous digestive enzyme activities in rabbits fed on multi-enzyme feed additives during growing period. Thus, the objective of this investigation was to examine the effects of exogenous enzyme preparation on the activities of endogenous digestive enzymes, either in serum, tissues or intestinal contents and its effects on the histomorphology of GIT in growing rabbits.

\section{Materials and Methods}

\subsection{Animals and Location}

The study was conducted in the experimental rabbitry of Physiology Department, Faculty of Veterinary Medicine, Cairo University, Egypt from March to June, 2011 in accordance with the Chinese guidelines for animal welfare and approved by the animal welfare committee of Animal Science College, Zhejiang University. Twenty male rabbits of the New Zealand white breed, ( 8 weeks old) and approximately (1000 g body weight) were equally and randomly divided into two groups ( $\mathrm{n}=10$ rabbits per group). The rabbits were housed individually in commercial cages $(55 \times 60 \times 34 \mathrm{~cm})$, equipped with automatic drinkers and j-feeders. Daily lighting regime was $10-12$ hour photoperiod /day through both natural and fluorescent lighting. A commercial pelleted diet of $16.7 \%$ crude protein, $13.7 \%$ crude fiber and $2590 \mathrm{kcal}$ of digestible energy per kg (Atmida Feed Company, Egypt) was offered ad libitum. The diet was subjected to chemical analysis according to AOAC (1999). Rabbits of group (1) were kept untreated and served as a control. Group (2), kemzyme group, was supplemented with (0.1\%) "Kemzyme", a multi-enzyme blend of Kemin Agrifoods Europe, containing $3000 \mu / \mathrm{g}$ beta-glucanase, $5000 \mu / \mathrm{g}$ cellulase, $450 \mu / \mathrm{g}$ alfa-amylase and $450 \mu / g$ protease and lipase. Dose of supplemented additive was given mixed with the basal ration in the form of pellets. The experiment lasted for 8 weeks during which fresh, clean water was available at all times. Body weight was determined at the beginning and at the end of the experimental period.

\subsection{Samples Collection and Analysis}

At the end of 8 weeks of the experimental period blood samples were collected from 10 rabbits by slaughtering. Serum was obtained by centrifugation of samples at $860 \times \mathrm{g}$ for $20 \mathrm{~min}$ for determination of serum amylase, lipase, protease, glucose, total protein and total lipids.

The rabbits were immediately eviscerated for collection of pancreas, tissue segments of GIT, including duodenum, jejunum and ilium. Samples of intestinal digesta from different segments of GIT were also collected. The pancreas and GIT segments sampling procedure was conducted according to the method described by Uni et al. (1999). The

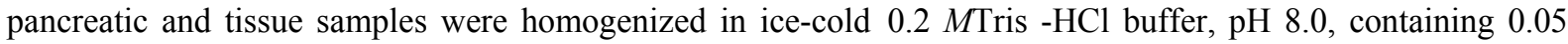


$M \mathrm{NaCl}$ in the ratio 1:4 (wt. /vol.). The homogenate was centrifuged at 3,000x $g$ for 15 min at $4{ }^{\circ} \mathrm{C}$, and the supernatant was stored frozen $\left(-70^{\circ} \mathrm{C}\right)$ for enzymes assay.

Homogeneous intestinal digesta samples were collected by massaging the tract from the distal end of the duodenum to the ileo-cecal junction using the method of Jin et al. (2000). Immediately, samples were diluted 10-fold, based on the sample weight, with ice -cold PBS (pH 7.0), homogenized for $1 \mathrm{~min}$, and sonicated for $1 \mathrm{~min}$ with 3 cycles at 30 -s intervals. The samples were then centrifuged at $18,000 \mathrm{x} g$ for $20 \mathrm{~min}$ at $4^{\circ} \mathrm{C}$. The supernatants were divided into small portions and stored at $-70^{\circ} \mathrm{C}$ for enzymes assay.

Amylase activity in sera, tissues and digesta was determined using the method of Somogyi (1960). Lipase activity was assayed using the method described by Tietz and Fiereck (1966). Protease activity was analyzed using the method of Lynn and Clevette-Radford (1984). Blood glucose level was determined according to Tietz and Fiereck (1966), total lipids according to Allain (1974) and total protein according to Doumas et al., (1981).

\subsection{Histomorphometry}

An intestinal segment of $5 \mathrm{~cm}$ was taken from every different segment of the intestine; duodenum and jejunum samples were taken $10 \mathrm{~cm}$ and $70 \mathrm{~cm}$ from the pyloric junction, an ileum segment was sampled $20 \mathrm{~cm}$ from the proximal end of the ileal- cecal junction, flushed with physiological saline and fixed in $10 \%$ formalin. Three cross sections for each sample were prepared after staining with hematoxylin and eosin using standard paraffin embedding procedures. Villus height was measured by averaging the height of 10 intact villi,from the tip of the villus to the villus crypt junction; crypt depth was defined as the depth of the invagination between adjacent villi by averaging 30 measurements. Morphological indices were measured using image processing and analysis system (Version 1, Leica Imaging System Ltd, Cambridge,UK).

\subsection{Statistical Analysis}

Statistical analysis was performed using the GLM procedure of SAS software (SAS Institute, 1988). A significance level of $P<0.05$ was used.

\section{Results}

Table (1) shows results of the average body weight and some blood biochemical parameters. Values indicate significant increase in average body weight of rabbits supplemented with kemzyme as compared to controls. Moreover, significant elevations in blood glucose levels, total lipids and total protein were also observed in rabbits supplemented with kemzyme in comparison to rabbits in control group.

Table (2) indicates activities of certain digestive enzymes in serum, pancreatic tissue and intestinal contents. Data identify shows a significant increase in the activities of serum amylase, lipase and protease in rabbits supplemented with kemzyme for 8 weeks as compared to controls. Meanwhile, activities of amylase, lipase, and protease in pancreatic tissue homogenates were observed to be significantly higher as compared to control rabbits. In addition, the activities of amylase, lipase and protease in intestinal content of kemzyme-supplemented rabbits were recorded to be significantly higher as compared to control animals.

Results tabulated in table (3) and figures (1, 2, 3 and 4) indicate villus length $(\mu \mathrm{m})$ and crypt depth $(\mu \mathrm{m})$ of small intestinal wall in rabbits supplemented with kemzyme for 8 successive weeks. There was a significant increase in crypt depth measurement in kemzyme supplemented rabbits as compared with control animals.

At the same time the villus length of the kemzyme groups indicated a mathematical increase without statistical significance with high figures of standard error (high individual variation).

\section{Discussion}

The rabbit's gastrointestinal physiology is a complex system that centers around separation of digestible and indigestible components of the diet. The benefits of exogenous enzyme supplementation are well documented (Bedford and Classen, 1992). These enzymes can partially hydrolyze the non starch polysaccharides (NSP), reduce the viscosity of gut contents, and result in improvements in nutrient absorption. Several studies have been attempted for incorporating exogenous enzymes into rabbit diets to improve nutrients availability (Falcao-e-Cunha et al., 2007). Some of them could not detect any significant effect of enzymes on rabbit performances (Falcão-e-Cunha et al, 2004), Others, showed that dietary addition of proteases reduced the ileal flow and mortality in fattening period of rabbits(Garciaet al., 2004, 2005, and 2006) of rabbits besides improving feed conversion ratio (Eiben et al., 2004). In some trials when cellulase and enzyme pool (xylanase, b-glucanase, b-gluccosidase, pentosanase, myloglucosidase, acid and neutral protease) were added, the authors got significant improvements in NDF and ADF digestibilities. In the present study, a significant increase in the average body weight, blood glucose levels, total lipids and total protein were observed in growing rabbits supplemented with kemzyme for 8 weeks. These finding corroborated earlier observations of Saleh et al., (2006) who found that kemzyme supplementation to the ration of growing turkey toms resulted in a significant increased level of blood 
glucose, total proteins and lipids. They attributed such finding to the improved digestibility and absorbability of different dietary elements, including carbohydrates, fat and proteins that was induced by the addition of exogenous enzymes. Such enrichment of bird's metabolic pools actively affects the blood levels of basic nutrients (Mathlouthi et al., 2003). Moreover, Abdl-Rahman et al., (2010) suggests that, multi-enzyme feed additives for rabbits could lead to favorable modifications in GIT environment presumably, acidification of cecal contents and stabilization of ammonia nitrogen concentrations. These alterations should be considered as an advantage, as they improve the impact of the supplemented enzymes on cecal fermentation pattern and rabbit metabolism that might lead to the higher body weight obtained in rabbits supplemented with kemzyme.

According to the obtained data in the present study, the activities of amylase, lipase and protease were significantly increased in serum, pancreatic homogenate and intestinal contents of rabbits supplemented with kemzyme for 8 weeks. Until recently, it was assumed that the proteolytic activity in the GIT ecosystem would rapidly inactivate unprotected enzyme feed additives (Chesson, 1994; Kung, 1996). This was conceded in the results of Kopecny' et al., (1987), who reported rapid inactivation of a cellulase preparation by Trichodermareesei by proteases from ruminal bacteria. More recently, different feed enzyme additives were reported to be more stable in the rumen than were previously thought possible, and this stability has been reported to depend on origin and type of activity (Hristov et al., 1998 a b). The results obtained by Morgavi et al., (2001) suggest that exogenous enzymes can survive in the intestine and exert their action on available substrates. The increased enzymatic activities in the intestinal content might be contributed to the sum of exogenous and endogenous enzymes action. Another possible factor responsible for such an increased enzymatic activity could be the 'favorable change in $\mathrm{pH}$ of GI tract' mediated by exogenous enzymes (Abdl-Rahman et al., 2010).

Moreover, the increased availability of nutrients (substrates) inside the GIT, most probably, the cause of increased activity and secretion of such digestive enzymes from the glandular mother cells (exocrine pancreatic cells) as a positive feedback response which is mainly neural factors instead of gut hormones (Murai et al., 2000 ). Another explanation is based on the conservation model of digestive enzymes which was proposed by Rotheman et al., (2002), and has been proved by Onderci et al., (2006) who pointed out that a large portion of the digestive enzymes secreted by the pancreas are absorbed into blood and recycled in an enteropancreatic circulation.

The morphological changes recorded in the intestinal mucosa (increased villus length and crypt depth) might be complementary changes to meet the increased rates of digestion and absorption mediated through the coupled activities of exogenous and endogenous digestive enzymes or due to elimination of toxic molecules and degradation of large-size diet protein.

Many studies have suggested that the morphological changes observed in the villi area so due to transient hypersensitivity to antigenic components of the diet (Lalles et al., 1993; Hong et al., 2004). Antigenic materials in diet proteins are associated with villus atrophy, increased crypt cell mitosis, and crypt hyperplasia, and there by cause a malabsorption syndrome (Kenworthy and Allen, 1966; Miller et al., 1984a, b). Similarly, the improvement of intestinal morphology may be associated with the degradation of antigenic materials after enzymatic fermentation. It was reported that increased enzymatic fermentation could degrade large-size protein to small-size peptides (Kiers et al., 2003; Hong et al., 2004). The improvement of digestive enzyme activity and intestinal mucosa morphology in rabbits supplemented by kemzyme may be partially responsible for the higher growth rate obtained in the present study.

\section{Conclusion}

In conclusion, supplementing growing rabbits with exogenous digestive enzymes (Kemzyme) was associated with improved digestive enzyme activities and intestinal mucosa morphology coupled with higher growth rate. It also seemed that the exogenous enzymes did not adversely affected with the endogenous proteolytic activity and might be mediate their action either locally or through activating the rate of synthesis and secretion of endogenous digestive enzymes.

\section{References}

Abdl-Rahman M. A., Sawiress, F. A. R., \& Sohair Y. Saleh. (2010). Effect of Kemzyme- Bentonite Co-supplementation on Cecal Fermentation and Metabolic Pattern in Rabbit. Journal of Agicultural Science, Vol. 2, No. 3, Sept. 2010.

Allain, C. (1974). Enzymatic determination of serum total lipids. Clin. Chem., 20:470-475.

AOAC. (1999). Association of Official Analytical Chemists. Official Methods of Analysis, 16th ed., vol. 2, Washington D.C., USA.

Bedford, M. R., \& H. L. Classen. (1992). Reduction of intestinal viscosity through manipulation of dietary rye and pentosanase concentration is effected through changes in the carbohydrate composition of the intestinal aqueous phase and results in improved growth rate and feed conversion. J.Nutr., 560-569. 
Bolis S., Castrovilli C., Rigoni M., Tedesco D., \& Luzi F. (1996). Effect of enzymes addition in diet on protein and energy utilization in rabbit. In Proc.: 6th World Rabbit Congress, Toulouse, France, 111-115.

Brenes, A. M. Smith, W.Guenter, \& R.R. Marquardt. (1993). Effect of enzyme supplementation on the performance and digestive tract size of broiler chickens fed wheat- and barley-based diets. Poult.Sci., 72:1731-1739.

Campbell, G. L., \& Bedford, M. R. (1992). Enzyme applications for monogastric feeds: A review. Can. J. Anim.Sci., 72:449. http://dx.doi.org/10.4141/cjas92-058

Cheeke, P. R., W. K. Sanchez \& Patton, N. M. (1985). Protein requirements for optimal growth and reproduction for rabbits. Nutr.Abst. Rev., 56: 331.

Chesson, A. (1994). Manipulation of fibre degradation: An old theme revised. In: T. P. Lyons and K. A. Jacques (ed.) Biotechnology in the Feed Industry. Proc. Alltech's 10th Ann. Symp. Nottingham University press, Loughborough, U.K.pp 83-98.

Choct, M., R. J. Hughes, \& M. R. Bedford. (1996). Effects of a xylanase on individual bird variation, starch digestion throughout the intestine, and ileal and caecal volatile fatty acid production in chickens fed wheat. $B r$. Poult. Sci., 40:419-422. http://dx.doi.org/10.1080/00071669987548

Doumas, B., Bayse, D. \& Carter, R. (1981). A candidate reference method for determination of total protein in serum. (I) development and validation. Clin. Chem., 27:1642-1650.

Eiben C.S., Mézes M., Zijártó N., Kustos K., Gódor-Surmann K., \& Erdélyi M. (2004). Dose-dependent effect of cellulose supplementation on performance of early-weaned rabbit. In Proc. 8th World Rabbit Congress, Puebla, México, 799-804.

Falcão-e-Cunha L., Reis J., Freire J.B., \& Castro-Solla L. (2004). Effects of enzyme addition and source of fiber on growth and fibrolytic activities of growing-finishing rabbits. In Proc.: 8th World Rabbit Congress, Puebla, México, 1532-1537.

Falcao-e-Cunha, L., Castro-Solla, L., Maertens, L., Marounek, M., Pinheiro, V., Freire, J., \& Mour, J. L. (2007). Alternatives to antibiotic growth promoters in rabbit feeding: a review. World Rabbit Science, 15, $127-140$.

Fernández C., Merino J.M., Carabaño R. (1996). Effect of enzyme complex supplementation on diet digestibility and growth performance in growing rabbits. In Proc.: 6th World Rabbit Congress, Toulouse, France, 163-166.

García A.I., de Blas J.C, Carabaño R. (2004). Effect of diet (casein-based or protein-free) and caecotrophy on ileal endogenous nitrogen and amino acid flow in rabbits. Anim. Sci., 79: 231-240.

García A.I., García J., Corrent E., Chamorro S., García-Rebollar P., De Blas J.C., \& Carabaño R. (2005). Effect of rabbit age, type of protein and feed enzyme addition on the apparent dry matter and crude protein digestibility of rabbit feed. In: Proc. 11émes Journées de la RechercheCunicole, 2005 November, Paris, France, 197-200.

García J., García A.I., GarcíaRebollar P., De Blas J.C., \& Carabaño R. (2006). Effects of source of protein and enzyme supplementation on performance of fattening rabbits. World Rabbit Sci., 14, 59.

Hasanat, M. S. Hossain, M. E. Mostari M. P. \& Hossain M. A. (2006). Effect of concentrate supplementation on growth and reproductive performance of rabbit under rural condition. Bangl. J. Vet. Med., 4 (2): 129-132.

Hong, K. J., C. H. Lee, \& S. W. Kim. (2004). Aspergillusoryzae GB-107 fermentation improves nutritional quality of food soybeans and feed soybean meals. J. Med. Food, 7:430-434. http://dx.doi.org/10.1089/jmf.2004.7.430

Hristov, A. N., T. A. McAllister, \& K.-J.Cheng. (1998a). Effect of dietary or abomasal supplementation of exogenous polysaccharide- degrading enzymes on rumen fermentation and nutrient digestibility. J.Anim. Sci., 76:3146-3156.

Hristov, A. N., T. A. McAllister, \& K.-J.Cheng. (1998b). Stability of exogenous polysaccharide-degrading enzymes in the rumen. Anim. Feed Sci. Technol., 76:161-168. http://dx.doi.org/10.1016/S0377-8401(98)00217-X

Jin, J., Y. W. Ho, N. Abdullah, \& S. Jalaludin. (2000). Digestive and bacterial enzyme activities in broilers fed diets supplemented with lactobacillus cultures. Poult. Sci., 79:886-891.

Kenworthy, R., \& W. D. Allen. (1966). The significance of Escherichia coli to the young pig. J. Comp. Pathol., 76:31-44. http://dx.doi.org/10.1016/0021-9975(66)90045-4

Kiers, J. L., J. C. Meijer, M. J. R. Nout, F. M. Rombouts, M. J. A. Nabuurs, \& J. Meulen. (2003). Effect of fermented soya beans on diarrhoea and feed efficiency in weaned piglets. J. Appl. Microbiol., 95:545-555. http://dx.doi.org/10.1046/j.1365-2672.2003.02011.x 
Kopecny, J., M. Marounek, \& K.Holub. (1987). Testing the suitability of the addition of Trichodermaviridecellulases to feed rations for ruminants. Zivoc.Vy'roba., 32:587-592.

Kung, L. (1996). Direct-fed microbial and enzyme feed additives. In: S. Muirhead (ed.) Direct-Fed Microbial, Enzyme and Forage Additive Compendium. vol.3. pp15-20.The Miller Publishing Co., Minnetonka, MN.

Lalles, J. P., H. Salmon, N. P. M. Bakker, \& G. H. Tolman. (1993). Effects of dietary antigens on health, performance and immune system of calves and piglets. Pages 253-270 in Recent Advances of Research in Antinutritional Factors in Legume Seeds. A. F. B. van der Poel, J. Huisman, and H. S. Saini, ed. WageningenPers, the Netherlands.Miller, B. G., T. J. Newby, C. R.

Lynn, K. R., \& N. A. Clevette-Radford. (1984). Purification and characterization of hevin, a serin protease from Heveabrazilliensis. Biochem. J., 23:963-964.

Mathlouthi, N., Juin, H. \& Larbier, M. (2003). Effect of xylanase and beta-glucanase supplementation of wheat- or wheat- and barley-based diets on the performance of male turkeys. Br. Poult. Sci., 44:291-8. http://dx.doi.org/10.1080/0007166031000096498

Miller, B. G., T. J. Newby, C. R. Stokes, \& F. J. Boame. (1984a). Influence of diet on post-weaning malabsorption and diarrhoea in the pig. Res. Vet. Sci., 36:137-145.

Miller, B. G., T. J. Newby, C. R. Stokes, D. J. Hampson, P. J. Brown, \& F. J. Boame. (1984b). The importance of dietary antigen in the cause of postweaning diarrhea in pigs. Am. J. Vet. Res., 45:1730-1737.

Morgavi, D. P., Beauchemin, K. A., Nsereko, V. L., Rode, L. M. McAllister, T. A. A. D. Iwaasa, A. D. Wang, Y. \& Yang W. Z. (2001). Resistance of feed enzymes to proteolytic inactivation by rumen microorganisms and gastrointestinal proteases. J. Anim. Sci., 79:1621-1630.

Murai, A., S. Satoh, J. Okumura \& M. Furuse. (2000). Factors regulating amylase secretion from chicken pancreatic acini in vitro. Life Sci., 66:585-591. http://dx.doi.org/10.1016/S0024-3205(99)00631-1

Onderci, M., N. Sahin, K. Sahin, G. Gikim, A. Aydin, I. Ozercan \& S. Aydin. (2006). Efficacy of supplementation of $\alpha$-amylase producing bacterial culture on the performance, nutrient use, and gut morphology of broiler chickens fed a corn-based diet. Poult. Sci., 85:505-510.

Remois G., Lafargue-Hauret P. \& Rouillere H. (1996). Effect of amylases supplementation in rabbit feed on growth performance. In Proc.:6th World Rabbit Congress, Toulouse, France, Vol. 1, 289-292.

Rothman, S., C. Liebow \& L. Isenman. (2002). Conservation of digestive enzymes. Physiol. Rev., 82:1-18.

Saleh, S.Y.; Attia, K.A. \& Amal, A.Z. (2006). Effect of multi-enzymes feed additive on performance and some metabolic parameters in turkeys. Kafr EL-Sheikh Vet. Med. J., 4 (1):1307-1319.

SAS Institute. (1988). SAS User's Guide: Statistics. SAS Inst. Inc., Cary, NC.

Somogyi, M. (1960). Modification of two methods for the assay of amylase. Clin. Chem., 6:23-27.

Tietz, N. W., \& E. A. Fiereck. (1966). A specific method for serum lipase determination. Clin.Chim.Acta, 13:352-355. http://dx.doi.org/10.1016/0009-8981(66)90215-4

Uni, Z., Y. Noy, \& D. Sklan. (1999). Posthatch development of small intestinal function in the poult. Poult. Sci., $78: 215-222$.

Xiangmei, G. (2008). Rabbit feed nutrition study for intensive, larg-scale meat rabbit breeding. MEKARN Workshop 2008: Organic rabbit production from forages. Qingdao Kangda Food company Limited, KangdGroupQingdao, 266400, China.

Table 1. Body weight, blood glucose total lipids and total protein levels of rabbits supplemented with Kemzyme at the end of experimental period ( 8 weeks)

\begin{tabular}{|l|c|c|}
\hline \multicolumn{1}{|c|}{ Groups } & Control & Kemzyme \\
\hline Parameters & $2200 \pm 42.12$ & $2450 \pm 45.30^{*}$ \\
\hline Body weight $(\mathrm{g})$ & $88.20 \pm 8.02$ & $122.10 \pm 9.22^{*}$ \\
\hline T. lipids $(\mathrm{g} / \mathrm{dl})$ & $220.10 \pm 18.19$ & $295.20 \pm 22.20^{*}$ \\
\hline T. protein $(\mathrm{g} / \mathrm{dl})$ & $4.02 \pm 0.66$ & $5.93 \pm 1.02^{*}$ \\
\hline
\end{tabular}

Values are means $\pm S E$, ( $n: 10$ rabbits / group).

Values having the mark (*) are significantly different from the corresponding control values at $(P<0.05)$. 
Table 2. Activities of digestive enzymes in rabbits supplemented with Kemzyme at the end of experimental period (8 weeks)

\begin{tabular}{|l|l|l|l|l|l|l|}
\hline \multirow{2}{*}{ Samples } & \multicolumn{2}{c|}{ Control } & \multicolumn{3}{c|}{ Kemzyme } \\
\cline { 2 - 7 } & Amylase & Lipase & Protease & Amylase & Lipase & Protease \\
\hline Serum (U/L) & $117.0 \pm 8.3$ & $172.0 \pm 18.3$ & $72.0 \pm 6.2$ & $211.0 \pm 17.2^{*}$ & $221.0 \pm 13.0^{*}$ & $99.0 \pm 5.0^{*}$ \\
\hline Pancreas (U/g) & $295.0 \pm 19.4$ & $90.0 \pm 11.3$ & $90.0 \pm 12.4$ & $333.0 \pm 20.1^{*}$ & $148.0 \pm 15.8^{*}$ & $118.4 \pm 14.3^{* *}$ \\
\hline Intestinal content (U/g) & $105.3 \pm 12.4$ & $68.3 \pm 5.3$ & $62.6 \pm 6.5$ & $185.0 \pm 13.0^{*}$ & $98.2 \pm 7.40^{*}$ & $102.0 \pm 4.0^{*}$ \\
\hline
\end{tabular}

Values are means $\pm S E$ ( $n: 10$ rabbits / group).

Values having the mark (*) are significantly different from the corresponding control values at $(P<0.05)$.

Table 3. Villus length $(\mu \mathrm{m})$ and crypt depth $(\mu \mathrm{m})$ of small intestinal segments in rabbits supplemented with Kemzyme for 8 weeks

\begin{tabular}{|l|l|l|l|l|}
\hline \multirow{2}{*}{ Groups } & \multicolumn{2}{|c|}{ Control } & \multicolumn{2}{c|}{ Kemzyme } \\
\cline { 2 - 5 } Segment & Villus length & Crypt depth & Villus length & Crypt depth \\
\hline Duodenum & $84.00 \pm 5.77$ & $21.66 \pm 2.28$ & $104.00 \pm 16.65$ & $44.25 \pm 3.08^{*}$ \\
Jejunum & $135.00 \pm 18.16$ & $44.25 \pm 7.56$ & $138.75 \pm 18.30$ & $72.00 \pm 10.23^{*}$ \\
Ileum & $166.87 \pm 18.88$ & $39.68 \pm 0.01$ & $236.19 \pm 14.41$ & $57.91 \pm 4.42^{*}$ \\
\hline
\end{tabular}

Values are means $\pm S E$, ( $n: 10$ rabbits / group).

Values having the mark $(*)$ are significantly different from the corresponding control values at $(P<0.05)$.

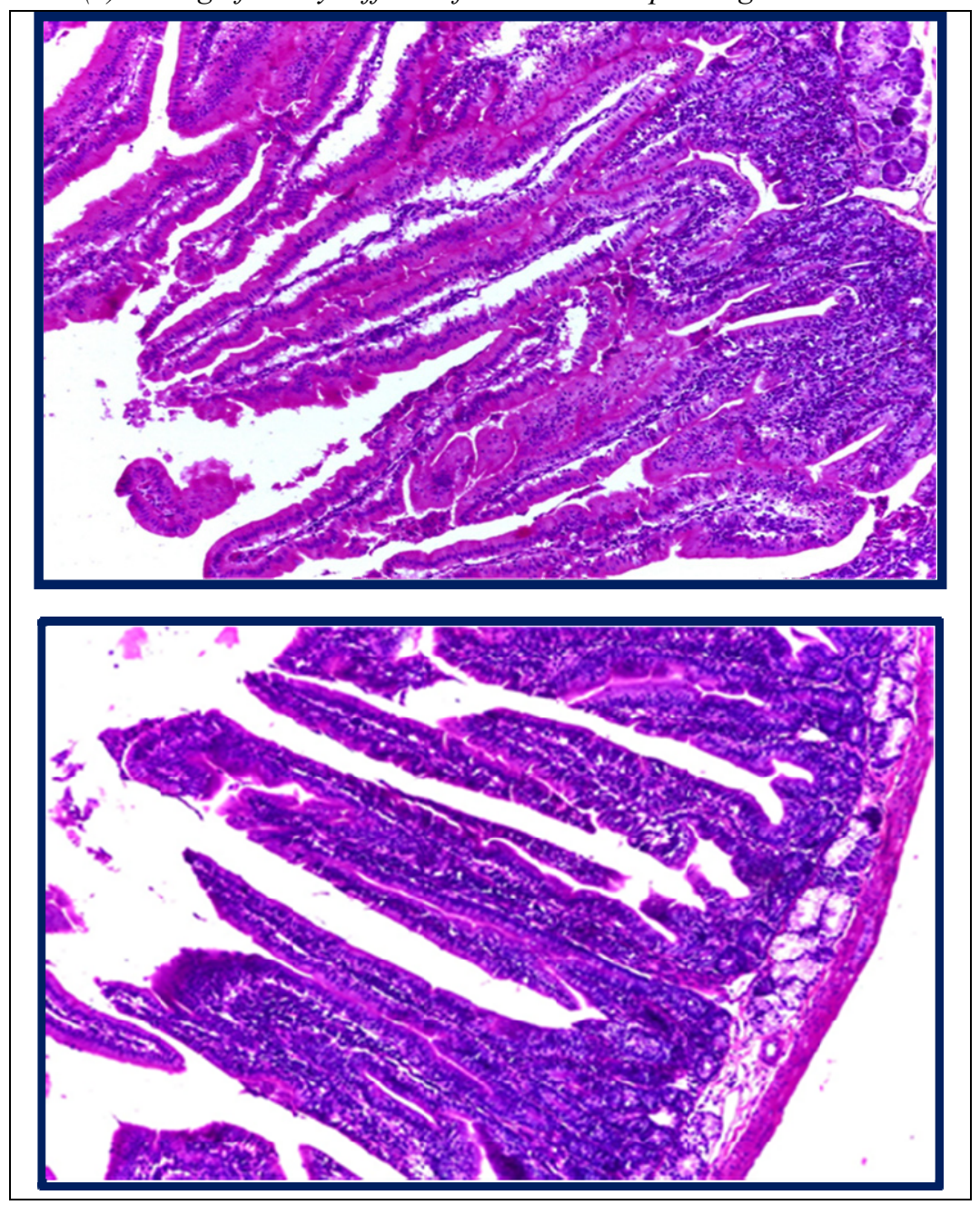

Figure 1. Villus of duodenum wall (Upper) control and (Lower) kemzyme supplemented rabbits (x 40) 

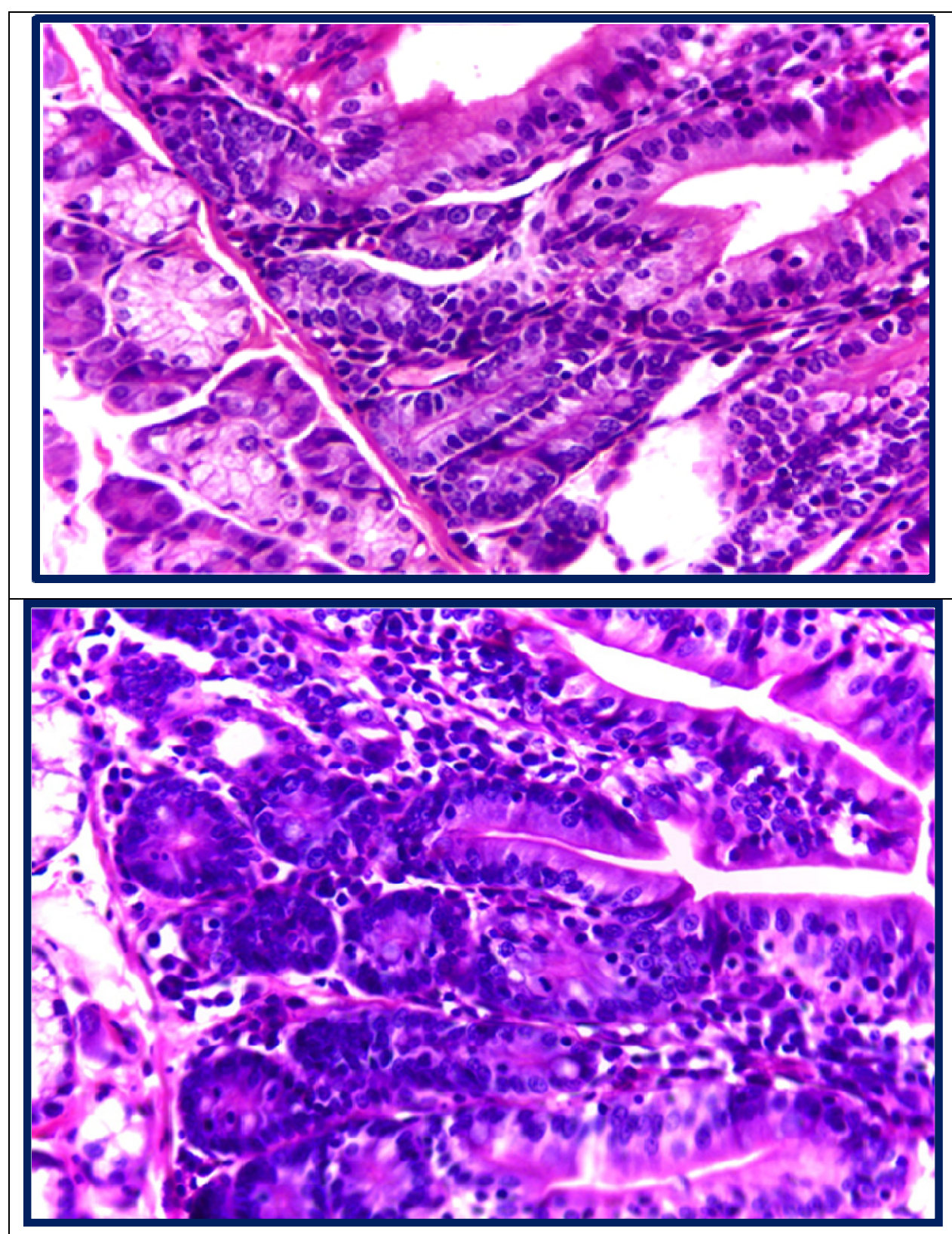

Figure 2. Crypt depth of duodenum wall (Upper) control and (Lower) kemzyme supplemented rabbits (x 80) 


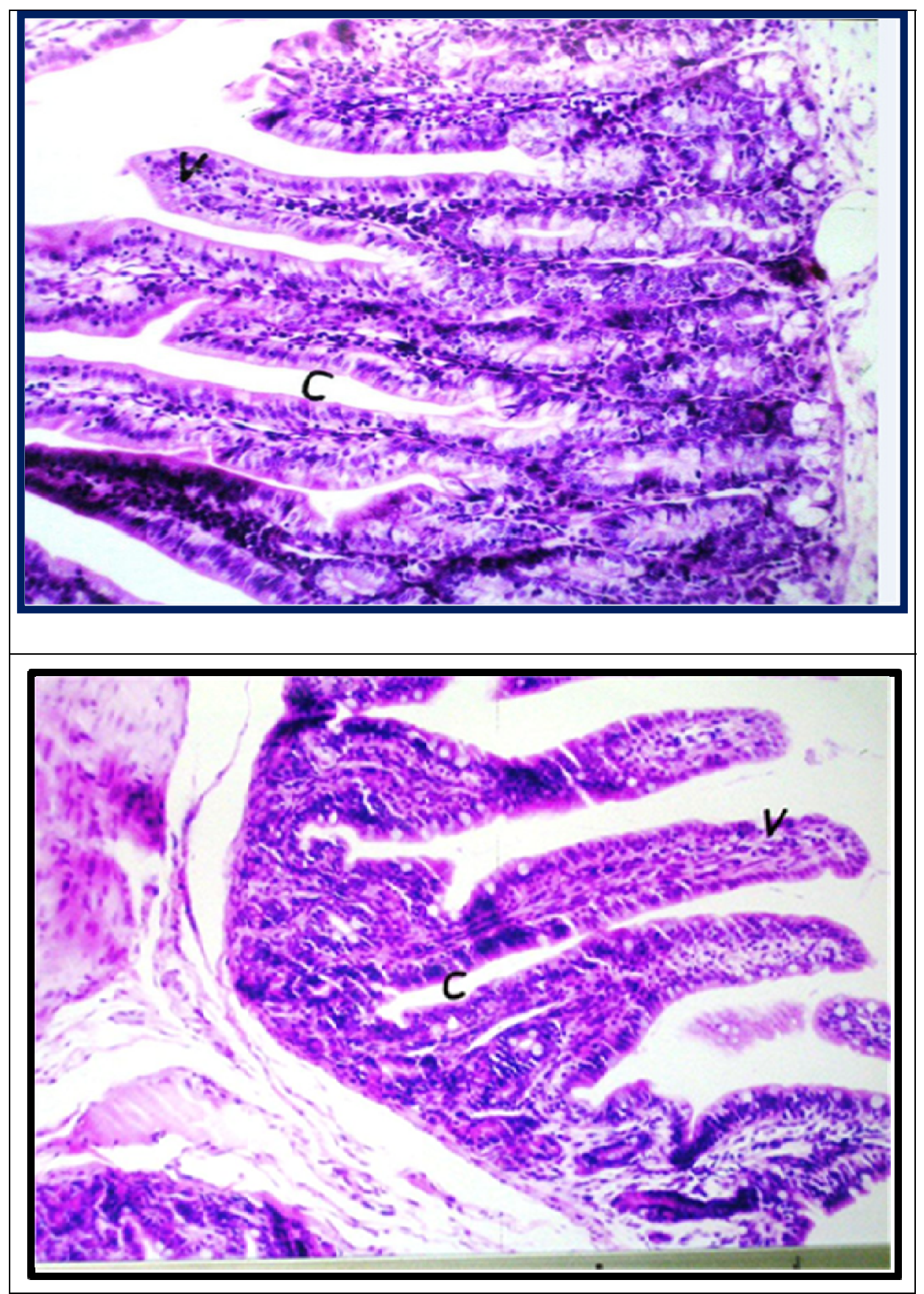

Figure 3. Villus and crypt depth of jejunum wall (Upper) control and (Lower) kemzyme supplemented rabbits (x60) 

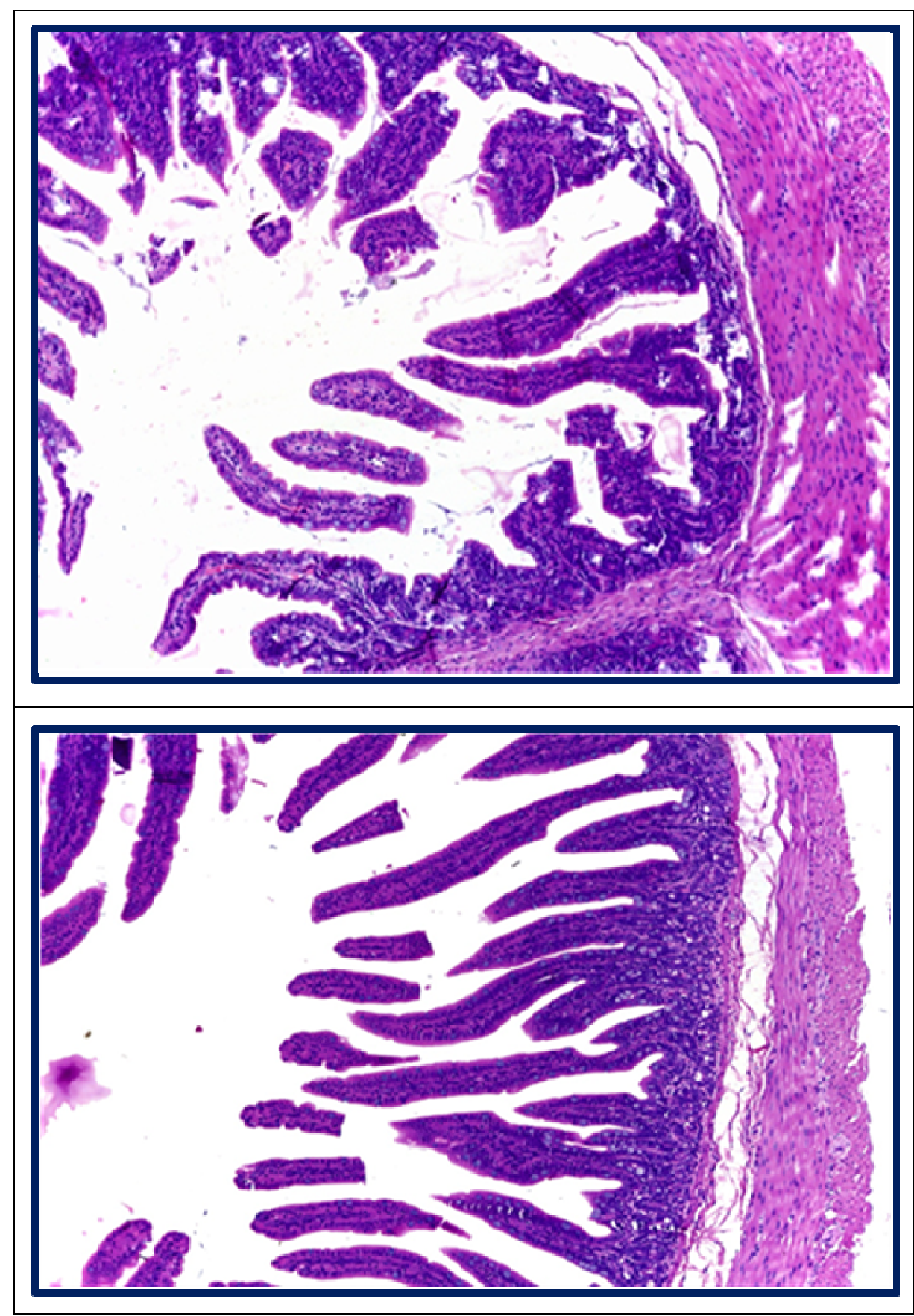

Figure 4. Villus and crypt depth of ileum wall (Upper) control and (Lower) kemzyme supplemented rabbits (x40) 